\title{
Optimalisasi Peran Orang Tua Dalam Memahami Remaja Generasi Milenial
}

\author{
Ernawati, Galih Fajar Fadillah', Alfin Miftahul khairi² \\ 1,2 Fakultas Ushuluddin dan Dakwah IAIN Surakarta \\ ernawatikonseling@gmail.com
}

\begin{abstract}
The background of this study is still a less harmonious relationship between parents and children, this has a significant impact on the existing emotional barrier. Moreover the challenges in the challenges of today's generation of adolescents. Parents as the first person known by adolescents to get it can be a good example, provide support to adolescents and parents can support teenagers, not only need physical and psychological needs and religious needs. The cases issued in the newspaper and online media are currently very alarming. Not infrequently support with the heart to act harshly, even to kill the lives of the fruits of victory. The purpose of this study is to describe the optimization of the role of parents in the participation of millennial generation adolescents. This research is applied qualitative research (applied qualitative research) and uses Phenomenological Interpretative Analysis (PAI), data collection techniques using interviews and observation as well as documentation. after the data is collected then analyzed with descriptive analysis. The results of this study prove the importance of the role of parents in the struggle of the younger generation. Optimizing the role of parents is grouped into 4 categories, namely optimization in the role of meeting the economic, physical, psychological, and religious needs.
\end{abstract}

Keywords: the role of parents, millennial generation

\begin{abstract}
Abstrak: Latar belakang penelitian ini adalah masih adanya relasi yang kurang harmonis antara orang tua dan anak, hal tersebut berdampak signifikan pada sekat emosional yang ada. Terlebih lagi tantangan dalam memahami remaja generasi milenial masa kini. Orang tua sebagai orang yang pertama kali dikenal oleh remaja hendaknya dapat menjadi teladan yang baik, memberikan dukungan pada remaja serta diharapkan orang tua dapat memahami remaja, tidak hanya kebutuhan fisik tentunya namun kebutuhan psikologis dan kebutuhan agama. Kasus-kasus yang beredar di media surat kabar dan media online saat ini sungguh sangat memprihatinkan. Tidak jarang orangtua dengan tega bertindak kasar, bahkan sampai menghabisi nyawa buah hatinya. Tujuan penelitian ini adalah untuk mendeskripsikan tentang optimalisasi peran orang tua dalam memahami remaja generasi milenial. Penelitian ini bersifat kualitatif terapan (applied qualitative research) dan menggunakan pendekatan Interpretative Phenomenology Analysis (IPA), teknik pengumpulan data menggunakan wawancara dan obersvasi serta dokumentasi. setelah data terkumpul kemudian dianalisis dengan analisis deskriptif. Hasil penelitian ini menunjukkan pentingnya optimalisasi peran orang tua dalam memahami remaja generasi milenial. Optimalisasi peran orang tua dikelompokkan dalam 4 kategori yaitu optimalisasi dalam peran pemenuhan kebutuhan ekonomi, fisik, psikologis, dan agama.
\end{abstract}

Kata kunci : peran orang tua, generasi milenial 


\section{WACANA}

\section{Pendahuluan}

Keluarga merupakan unit terkecil yang pertama kali di kenal oleh seorang individu termasuk remaja. Keluarga Sebagai unit sosial terkecil dalam masyarakat mempunyai peranan yang sangat besar dalam mempengaruhi kehidupan dan perilaku anak. Peran dan tanggung jawab orang tua mendidik anak dalam keluarga sangat besar, sebab ditangan orang tualah baik dan buruknya akhlak seorang anak dibentuk. Sebagaimana sabda Nabi "Sempurnanya iman seorang mukmin adalah mempunyai akhlak yang baik". Peran orang tualah yang sangat besar peranannya dalam menanamkan nilai-nilai kebaikan pada anak, agar ketika remaja hingga dewasa nanti anak menjadi lebih mandiri dan mampu menjadi pribadi yang bertanggung jawab. Harapan terbesar orang tua adalah ingin memiliki anak dalam hal ini anak usia remaja yang soleh, sopan, pandai bergaul, pintar mampu bertanggung jawab dan sukses. Tetapi harapan besar ini jangan sampai hanya menjadi angan. Perlu optimalisasi peran orang tua dalam mewujudkan harapan tersebut. Perlu dipahami oleh setiap orang tua bahwa kedudukan dan fungsi suatu keluarga dalam kehidupan manusia sangatlah penting dan fundamental, keluarga merupakan tempat penanaman nilai-nilai kebaikan yang pertama di kenal oleh setiap anak. Pada hakekatnya keluarga juga merupakan wadah pembentukan karekter masing-masing anggotanya, terutama anak dan remaja yang masih berada dalam bimbingan tanggung jawab orang tuanya.

Bagaimana orang tua untuk mewujudkan harapan sekaligus tanggung jawab tersebut? Terlebih dalam mendidik remaja zaman sekarang. Anak muda zaman sekarang di sebut dengan istilah generasi milenial. Generasi ini identik dengan berbagai kemudahan dalam perkembangan teknologi informasi. Hanya di generasi milenial ini segala sesuatu bisa di pesan dalam genggaman, yaitu smartphone. Bahkan generasi milenial bisa mengenal berbagai orang dari berbagai daerah bahkan dunia sekalipun meski belum pernah bertemu. Mereka saling bertegur sapa dalam dunia maya. Tentunya pengaruh baik dan buruk dengan kecanggihan teknologi tersebut pada generasi milenial sangat mudah didapatkan.

Dampak baik dari kecanggihan teknologi bagi remaja saat ini adalah kemudahan dalam mengakses layanan teknologi dan informasi, kemudahan dalam berkomunikasi memungkinkan setiap remaja menjalin hubungan sosial yang lebih luas dari berbagai daerah bahkan berbagai negara di belahan dunia. Hal tersebut memungkinkan para remaja generasi milenial mengakses informasi dengan kecepatan tinggi serta mendapatan kemudahan dalam berbagai hal.

Di sisi lain dampak buruk dari kecanggihan teknologi informasi pada generasi milenial adalah mudahnya para remaja generasi milenial terpengaruh berita, tayangan, dan informasi buruk lain nya lainnya yang sangat mudah di akses dan disebarkan sehingga remaja generasi 


\section{WACANA}

milenial yang masih berada dalam fase labil dengan keingintahuan yang besar akhirnya mudah terpengaruh. Fakta menunjukan tingkat kenakalan remaja generasi milenial menunjukkan kenaikan yang sangat signifikan.

Ayuningtyas (2011) memaparkan berdasarkan data dari Pusat Pengendalian Gangguan Sosial DKI Jakarta bahwa pada 2009 terdapat 0,08 persen atau 1.318 dari 1.647 .835 siswa SD, SMP, dan SMA di DKI Jakarta terlibat tawuran, dan angka ini meningkat dari tahun tahun sebelumnya. Hingga tahun-tahun ke depan jumlah tersebut kian menunjukkan peningkatan. Fakta lain juga menyebutkan tentang orang tua yang tidak memahami anak dapat menimbulkan depresi berat baik depresi pada orang tua maupun berdampak depresi pada anak. Kasus pembunuhan yag dilakukan orang tua pada anak bisa kita jumpai di Cirebon salah satunya. Tahun 2017, N si ibu korban tega menganiaya anak kandungnya NQZ sampai tewas. Ketika ditetapkan menjadi tersangka, polisi belum mengetahui motif $\mathrm{N}$ menganiaya anaknya karena masih depresi berat (kompas.com).

Fakta kasus- kasus tentang generasi milenial di lapangan saat ini banyak kita jumpai, seperti kasus bunuh diri yang dilakukan oleh seorang remaja SMP hanya karena ia gagal dalam memasuki sekolah favoritnya, belum lama kita juga mengetahui hilangnya seorang remaja bersama seseorang yang dikenalnya melalui media sosial, kasus tawuran remaja yang berawal dari konflik di media sosial yang di berujung ke tawuran antar pelajar, serta kasus-kasus penipuan di kalangan anak remaja hingga kasus pelecehan seksual. Mirisnya adalah remaja kita tidak hanya menjadi korban beberapa di antaranya menjadi tersangka hingga terpaksa harus berhadapan dengan hukum. Hal tersebut tentu saja membutuhkan perhatian yang cukup besar dari berbagai pihak. Karena itu peran orang tua perlu di optimalkan agar orang lebih dapat memahami para anak remaja generasi milenial sehingga harapannya kasus-kasus remaja dapat teratasi dengan baik. Banyaknya tindakan kriminal yang dilakukan generasi milenial saat ini tidak terlepas dari kelengahan bahkan kurag optimalnya para orang tua dalam mendidik anakanaknya. Karena itu peniliti tertarik meneliti tentang bagaimana peran orang tua dalam mengoptimalkan pemahamannya tentang remaja generasi milenial.

1. Peran Orangtua

\section{a. Sebagai Pendidik}

Peran orangtua sebagai pendidik pertama dan utama adalah amanah Allah SWT atas setiap orangtua. Peranan orangtua sebagai pendidik pertama dan utama bagi anak juga dikarenakan secara hereditas mereka ditakdirkan menjadi orangtua dari anak yang dilahirkan, maka secara tidak langsung, mau tidak mau orangtualah yang menjadi penanggungjawab pertama dan utama. Kaidah inilah yang telah diakui oleh semua agama dan semua sistem nilai yang dikenal manusia (Ahmad, 1992). 


\section{WACANA}

Hal tersebut mencerminkan bahwa setiap orangtua mempunyai peran utama dalam pembinaan dan pendidikan anak-anaknya di keluarga, karena kodrat dan fungsinya mengarah pada tugas tersebut (Ziani dan Mujib, 1991). Dengan demikian orangtua harus memberikan perhatian, kasih sayang serta pendidikan yang terbaik untuk anak-anaknya agar menjadi manusia yang baik pula.

Ada pepatah arab yang menjelaskan bagaimana penting peran ibu dalam pendidikan anaknya (Al Hisyamy. 1997), yang berbunyi:

$$
\text { الأعراق طيب شعبا اعددت * اعددتها إذا مدرسة الأم }
$$

Artinya: Seorang ibu adalah madrasah apabila engkau mempersiapkannya, berarti engkau telah mempersiapkan suku bangsa dan generasi yang baik. Seorang ibu adalah guru pertama dan dari semua guru pertama yang pengaruhnya menyentuh jagad raya.

Faktor keluarga benar-benar memberikan pengaruh yang sangat besar bagi anak. Keluarga sebagai lingkungan awal anak sangat berpengaruh terhadap pendidikan anak. Oleh karena itu situasi yang baik harus diciptakan yaitu situasi terdidik, dan dalam hal ini dituntut kesadaran dari orangtua selaku penanggungjawab atas anak-anaknya.

Pendidikan merupakan upaya pengembangan aspek fitrah anak agar dapat berkembang secara maksimal. Dalam hal ini lingkungan keluarga merupakan lingkungan informal bagi anak. Di dalam rumahlah anak lebih banyak menghabiskan waktu kesehariannya bersama kedua orangtua dan orang dewasa lainnya di rumah. Sebagaimana hadist Rasulullah SAW tentang pentingnya orangtua dalam memperhatikan pendidikan anak-anaknya. Yang berbunyi:

$$
\text { (منصور لإن سعيد و الرزاق عبد رواه) أدو هم و الخير أهليكم و أو لادكم علموا }
$$

Artinya: Ajarkanlah kebaikan kepada anak-anak kalian dan didiklah mereka (HR. Abdur Ramilenialaq dan Said bin Mansur)

Dalam kaitannya, peran orangtua dalam membimbing anak tidak lebih dari seorang guru. Maka menurut Durkheim ada sejumlah aspek yang mempengaruhi kualitas pembelajaran dilihat dari faktor guru yaitu (Sanjaya, 2007):

\section{1) Teacher Formative Experience}

Meliputi jenis kelamin serta semua pengalaman hidup guru yang menjadi latar belakang sosial mereka. Yang termasuk ke dalam aspek ini diantaranya meliputi tempat asal kelahiran guru termasuk suku, latar belakang budaya dan adat istiadat, keadaan keluarga dari mana guru itu berasal.

\section{2) Teacher Training Experience}




\section{WACANA}

Meliputi pengalaman orang-orang yang berhubungan dengan aktifitas dan latar belakang guru. Misalnya jabatan atau sebagainya.

\section{3) Teacher Properties}

Adalah segala sesuatu yang berhubungan dengan sifat yang dimiliki guru. Misalnya sikap guru terhadap siswa, kemampuan atau intelegensi guru, motivasi dan kemampuan mereka baik kemampuan dalam merencanakan dan evaluasi pembelajaran maupun kemampuan dalam penguasaan materi pembelajaran.

b. Sebagai Motivator

Masa anak-anak adalah masa bermain dan juga masa dimana pertumbuhan anak berada dalam tahap perkembangan. Orangtua sangat berpengaruh besar dalam membimbing, mengontrol dan mengarahkan anaknya dalam kehidupan sehari-harinya. Mood anak yang sering berubah terkadang menjadi kendala sendiri bagi orangtua.

Beberapa psikolog menyebut motivasi sebagai konstruk hipotetis yang digunakan untuk menjelaskan keinginan, arah, intensitas dan perilaku yang diarahkan oleh tujuan. Menurut Sartain, motivasi disebut juga dengan drive yaitu suatu pernyataan yang kompleks pada suatu organisme yang mengarahkan tingkah laku terhadap suatu tujuan (goal) atau perangsang (incentive) (Purwanto. 2007). Oleh karena itu orangtua bisa menjadi motivator pribadi bagi anak-anaknya karena orang yang terdekat secara bathin adalah orangtua.

2. Remaja

Masa remaja adalah masa transisi dalam rentang kehidupan manusia, menghubungkan masa kanak-kanak dan masa dewasa (Santrock, 2002). Masa remaja disebut pula sebagai masa penghubung atau masa peralihan antara masa kanak-kanak dengan masa dewasa. Pada periode ini terjadi perubahan-perubahan besar dan esensial mengenai kematangan fungsi-fungsi rohaniah dan jasmaniah, terutama fungsi seksual (Kartono, 1995).

Remaja, yang dalam bahasa aslinya disebut adolescence, berasal dari bahasa Latin adolescare yang artinya "tumbuh atau tumbuh untuk mencapai kematangan". Bangsa primitif dan orang-orang purbakala memandang masa puber dan masa remaja tidak berbeda dengan periode lain dalam rentang kehidupan. Anak dianggap sudah dewasa apabila sudah mampu mengadakan reproduksi (Ali \& Asrori, 2006).

Masa remaja adalah masa transisi yang ditandai oleh adanya perubahan fisik, emosi dan psikis. Masa remaja, yakni antara usia 10-19 tahun, adalah suatu periode masa pematangan organ reproduksi manusia, dan sering disebut masa pubertas. Masa 


\section{WACANA}

remaja adalah periode peralihan dari masa anak ke masa dewasa (Widyastuti, Rahmawati, Purnamaningrum; 2009).

Pubertas (puberty) ialah suatu periode di mana kematangan kerangka dan seksual terjadi secara pesat terutama pada awal masa remaja. Akan tetapi, pubertas bukanlah suatu peristiwa tunggal yang tiba-tiba terjadi. Pubertas adalah bagian dari suatu proses yang terjadi berangsur-angsur (gradual) (Santrock, 2002).

Santrock (2002) menambahkan bahwa kita dapat mengetahui kapan seorang anak muda mengawali masa pubertasnya, tetapi menentukan secara tepat permulaan dan akhirnya adalah sulit. Kecuali untuk menarche, yang terjadi agak terlambat pada masa pubertas, tidak ada tanda tunggal yang menggemparkan pada masa pubertas.

Pada 1974, WHO (World Health Organization) memberikan definisi tentang remaja yang lebih bersifat konseptual. Dalam definisi tersebut dikemukakan tiga kriteria, yaitu biologis, psikologis, dan sosial ekonomi, sehingga secara lengkap definisi tersebut berbunyi sebagai berikut. Remaja adalah suatu masa di mana:

1) Individu berkembang dari saat pertama kali ia menunjukkan tanda-tanda seksual sekundernya sampai saat ia mencapai kematangan seksual.

2) Individu mengalami perkembangan psikologis dan pola identifikasi dari kanak-kanak menjadi dewasa.

3) Terjadi peralihan dari ketergantungan sosial-ekonomi yang penuh kepada keadaan yang relatif lebih mandiri ( Sarwono, 2011).

Dalam tahapan perkembangan remaja menempati posisi setelah masa anak dan sebelum masa dewasa. Adanya perubahan besar dalam tahap perkembangan remaja baik perubahan fisik maupun perubahan psikis (pada perempuan setelah mengalami menarche dan pada laki-laki setelah mengalami mimpi basah) menyebabkan masa remaja relatif bergejolak dibandingkan dengan masa perkembangan lainnya. Hal ini menyebabkan masa remaja menjadi penting untuk diperhatikan.

\section{Generasi Milenial}

Menurut Manheim (1952) generasi adalah suatu konstruksi sosial dimana didalamnya terdapat sekelompok orang yang memiliki kesamaan umur dan pengalaman historis yang sama. Lebih lanjut Manheim (1952) menjelaskan bahwa individu yang menjadi bagian dari satu generasi, adalah mereka yang memiliki kesamaan tahun lahir dalam rentang waktu 20 tahun dan berada dalam dimensi sosial dan dimensi sejarah yang sama. Definisi tersebut secara spesifik juga dikembangkan oleh Ryder (1965) yang mengatakan bahwa generasi adalah agregat dari sekelompok individu yang mengalami peristiwa - peristiwa yang sama dalam kurun waktu yang sama pula. 


\section{WACANA}

Howe \& Strauss $(1991,2000)$ membagi generasi berdasarkan kesamaan rentang waktu kelahiran dan kesamaan kejadian - kejadian historis. Pembagian generasi tersebut juga banyak dikemukakan oleh peneliti - peneliti lain dengan abel yang berbeda - beda, tetapi secara umum memiliki makna yang sama.

Sebagai contoh menurut Martin \& Tulgan (2002) Generasi Y adalah generasi yang lahir pada kisaran tahun 1978, sementara menurut Howe \& Strauss (2000) generasi Y adalah generasi yang lahir pada tahun 1982, hal tersebut terjadi karena adanya perbedaan skema yang digunakan untuk mengelompokkan generasi tersebut, karena peneliti - peneliti tersebut berasal dari Negara yang berbeda.

Pemahaman dasar mengenai pengelompokan generasi adalah adanya premis bahwa generasi adalah sekelompok individu yang dipengaruhi oleh kejadian - kejadian bersejarah dan fenomena budaya yang terjadi dan dialami pada fase kehidupan mereka (Nobel \& Schewe, 2003; Twenge, 2000), dan kejadian serta fenomena tersebut menyebabkan terbentuknya ingatan secara kolektif yang berdampak dalam kehidupan mereka (Dencker et al. 2008). Jadi kejadian historis, sosial, dan efek budaya bersama dengan faktor-faktor lain ini akan berpengaruh terhadap terbentuknya perilaku individu, nilai, dan kepribadian (Caspi \& Roberts, 2001; Caspi et.al, 2005).

Dari penjelasan tersebut ada 2 hal utama yang mendasari pengelompokan generasi, yaitu faktor demografi khususnya kesamaan tahun kelahiran dan yang kedua adalah faktor sosiologis khususnya adalah kejadian - kejadian yang historis, menurut Parry \& Urwin (2011) faktor kedua lebih banyak dipakai sebagai dasar dalam studi maupun penelitian tentang perbedaan generasi. Para ahli berpendapat bahwa generasi terbentuk lebih disebabkan karena kejadian atau event yang bersejarah dibanding dengan tahun kelahiran, sebagai contoh generasi Baby Boom dimulai pada rentang waktu dari tahun 1943 sampai dengan 1946 dan berakhir pada rentang waktu 1960 sampai dengan 1969. Generasi X dimulai dari rentang waktu yang bervariasi, yaitu dari tahun 1961 sampai dengan tahun 1965 dan berakhir pada tahun 1975 sampai dengan 1981.

Menurut Howe \& Strauss (2000), ada tiga atribut yang lebih jelas mengidentifikasi generasi dibanding dengan tahun kelahiran, atribut tersebut antara lain :

1) Percieved membership : persepsi individu terhadap sebuah kelompok dimana mereka tergabung didalamnya, khususya pada masa - masa remaja sampai dengan masa dewasa muda. 


\section{WACANA}

2) Common belief and behaviors : sikap terhadap keluarga, karir, kehidupan personal, politik, agama dan pilihan - pilihan yang diambil terkait dengan pekerjaan, pernikahan, anak, kesehatan, kejahatan.

3) Common location in history : perubahan pandangan politik, kejadian yang bersejarah, contohnya seperti: perang, bencana alam, yang terjadi pada masa - masa remaja sampai dengan dewasa muda.

\section{Metode Penelitian}

Penelitian ini bersifat kualitatif terapan (applied qualitative research) dan menggunakan pendekatan Interpretative Phenomenology Analysis (IPA). (Roller, 2015; Smith dkk., 2009). Dengan pendekatan ini penelitian bertujuan untuk memahami, menganalisis, dan mengeksplorasi bagaimana narasumber memaknai optimalisasi peran orang tua dalam memahami generasi milenial yang mereka lihat, amati atau bahkan mereka alami. Narasumber berasal dari para orang tua berjumlah 10 orang yang memiliki anak remaja dalam kategori generasi milenial berasal dari muslim dan non muslim yang didefinisikan sebagai remaja generasi milenial yang berumur antara 15-24 tahun (sesuai standard PBB). Selain itu narasumber juga dibatasi hanya pada mereka yang memiliki anak remaja usia tersebut serta subjek pendukung yaitu remaja generasi milenial berjumlah 10 remaja . Data di ambil dengan menggunakan wawancara dan observasi. Penelitian ini dilakukan pada bulan Oktober 2018.

Narasumber dipilih dengan menggunakan teknik pengambilan sampel disengaja (Intensity purposed sampling). Teknik ini bertujuan memilih narasumber penelitian sedemikian rupa agar dapat mencerminkan karakteristik kelompok yang diteliti serta memudahkan untuk analisis perbandingan pandangan, perilaku dan sikap mereka terhadap isu yang sedang diteliti. Total jumlah narasumber penelitian yang 20 orang. Mereka berasal dari orang tua siswa/siswi yang memiliki anak remaja usia sekolah tingkat pendidikan SMP dan SMA serta mahasiswa diberbagai perguruan Tinggi, asal kota mereka diantaranya Surakarta, Sukoharjo, Sragen, Boyolali dan Karanganyar.

\section{Hasil dan Pembahasan}

Peran orang tua terhadap anak anak nya terutama kepada remaja generasi milenial tentu sangatlah penting. Orang tua yang memiliki anak remaja generasi milenial tentu saja harus lebih ekstra optimal dalam berperan, orang tua di tuntut mampu memenuhi semua kebutuhan remaja generasi milenial agar memudahkan dalam penanganan dan mendidik generasi milenial. Sebab bila perna itu tidak dioptimalkan maka berbagai permasalahan remaja generasi milenial akan muncul.

Memahami remaja generasi milenial di era milineal saat ini merupakan tantangan besar bagi para orang tua. Orang tua tidak hanya harus mencerdasakan diri namun harus pula 


\section{WACANA}

bersikap bijak dalam mendidik para anak remajanya. Hal tersebut senada seperti yang di utarakan oleh Ahmad (1992) yang mengatakan bahwa Peran orangtua sebagai pendidik pertama dan utama adalah amanah Allah SWT atas setiap orangtua. Peranan orangtua sebagai pendidik pertama dan utama bagi anak juga dikarenakan secara hereditas mereka ditakdirkan menjadi orangtua dari anak yang dilahirkan, maka secara tidak langsung, mau tidak mau orangtualah yang menjadi penanggungjawab pertama dan utama. Kaidah inilah yang telah diakui oleh semua agama dan semua sistem nilai yang dikenal manusia.

Optimalisasi Peran Orang Tua dalam Memahami Remaja Generasi milenial

1. Peran orang tua dalam pemenuhan kebutuhan ekonomi

Orang tua memiliki peran untuk mencari nafkah untuk anak-anak meraka. Pemenuhan kebutuhan ekonomi ini menjadi hal pokok yang harus diperhatikan oleh orang tua. Sebab bila tidak terpenuhi maka permasalahan anak dalam hal ini remaja generasi milenial sangat mudah untuk timbul.

Penuturan salah satu subjek penelitian ini Ibu milenialHR (45 thn) menuturkan

"saya memiliki anak remaja usia SMP, anak saya tersebut seringkali protes pada saya bila saya tidak memberinya uang saku, padahal kondisi keuangan saya terkadang tidak mencukupi, saya kadang bingung sendiri mbak ngadepin anak muda jaman sekarang"(W1,milenialHR,02/10/2018)

"saya punya anak SMP kelas Dua bu, tapi sudah minta dibelikan motor gede, padahal harga motor itu tidak murah, saya tidak mengijinkan tapi kadang suami saya sering mengabulkan permintaan anak kesayangan nya itu"(W1, NE,02/10/2018)

"hidup kami ya pas-pasan mbk, makanya saya tidak menyarankan anak saya kuliah karena tidak ada biaya, tapi anak yang saya yang terakhir ini ngeyel tetap semangat pengen kuliah, padahal saya sm bapaknya gak ada biaya, kataya mau kuliah sambil kerja "(W1,ASW,13/10/2018)

"hmm pekerjaan saya ya begini ini mbak berdagang makanan keliling,suami saya kerja tapi jarang kasih uang buat saya, anak saya tiga, yang pertama SMP, tadi dia gak ngerti rekoso nya saya cari uang, saya sering nangis sendiri,ko yo anak saya gak mudeng rekosone ibue, tapi saya tetap harus cari uang buat mereka"(w1,IM,03/10/2018)

Hasil wawancara di atas menunjukkan bahwa peran orang tua dalam pemenuhan kebutuhan 


\section{WACANA}

ekonomi untuk anak-anak mereka menjadi peran yang harus di optimalkan. Seharusnya tanggung jawab dan peran orang tua tak hanya d satu pihak saja, pihak ayah atau ibu namun adalah kedua belah pihak. Optimalisasi kerjasama baik antara peran ayah dan peran ibu

tentu akan sangat memberikan pengaruh pada pemenuhan kebutuhan ekonomi anakanak mereka.

2. Optimalisasi peran pemenuhan kebutuhan Fisik pada remaja generasi milenial Peran orang tua untuk memberikan pemenuhan kebutuhan fisik anak juga tak dapat dikesampingkan. Orang tua yang bijak tentu harus mampu memberikan kebutuhan 4 sehat 5 sempurna untuk anak-anak mereka. Agar remaja dalam masa pertumbuhan dapat berkembag secara optimal.

“ya kami berusaha memenuhi kebutuhan fisik mereka mbk, ya makan minum yang sehat semampu kami" (W1, AS,14/10/2018)

"buat saya yang penting anak-anak saya kenyang walau saya harus susah payah mencari makanan kesukaan mereka,saya ingin anak-anak saya hidup dan tumbuh sehat" (W1, ABD, 10/10/2018)

"ya makan se adanya mbak, mau yang enak-enak ya gak bisa, wong kami kurang mampu"(w1,JM,11/10/2018)

3. Optimalisasi peran pemenuhan kebutuhan psikologis pada remaja generasi milenial Peran orang tua untuk memenuhi kebutuhan psikologis remaja generasi milenial menjadi mutlak dibutuhkan di era saat ini, sebab kebutuhan perhatian, kasih sayang, support dan dukungan psikologis akan sangat berpengaruh bagi tumbuh kembang kepribadian remaja generasi milenial. orang tua hendaknya mampu menjadi sahabat untuk anak-anak remeja generasi milenial.

" anak saya kalo curhat ya ke saya mbk, apa ja dia cerita jadi saya tahu dia deket sama siapa, karena sejak dulu saya membiasakan jadi sahabat bagi anak-anak saya" $(w 2, A M, 21 / 10 / 2018)$ 


\section{WACANA}

Enggak, jarang curhat sama saya, seringnya ya maenan HP aja, sampe susah dkasih tahunya(w2,SM,21/10/2018)

"kalo curhat ya ke temen-temen nya kayaknya sih, tapi anak saya itu kecanduan HP,sampe pusing saya, didalam kamar seharian betah dia asal ada $H P^{\prime \prime}(w 2, I K, 22 / 10 / 2018)$

Memahami psikologi remaja generasi milenial harusnya menjadi sebuah keharusan bagi para orang tua, dengan memahami psikologi remaja generasi milenial diharapkan permasalahan remaja dapat di pantau dan remaja bisa mendapatkan alternative solusi yang tepat dari orang tua. Bukan dari media social atau teman-temannya yang terkadang belum tepat dalam memberikan solusi terbaik pada remaja generasi milenial.

Hal tersebut sesuai pendapat beberapa psikolog yang menyebut orangtua bisa menjadi motivator pribadi bagi anak-anaknya karena orang yang terdekat secara bathin adalah orangtua. Orang tua harus mampu memberikan motivasi pada anak remaja dalam mengarahkan keinginan dan tujuan hidup para remaja. Menurut Sartain, motivasi disebut juga dengan drive yaitu suatu pernyataan yang kompleks pada suatu organisme yang mengarahkan tingkah laku terhadap suatu tujuan (goal) atau perangsang (incentive) (Purwanto. 2007). Oleh karena itu

4. Optimalisasi dalam Pemenuhan kebutuhan pendidikan Agama pada generasi milenial Pemenuhan kebutuhan agama menjadi pondasi pada remaja generasi milenial dalam berproses menjadi manusia harapan Tuhan. Optimaliasi peran orang tua dalam memberikan dasar-dasar pemahaman dan nilai-nilai kebaikan yang di ajakarkan dalam ajaran agama aka memberikan bekal yang akan sangat bermanfaat bagi remaja generasi milenial.

" kalo saya dari kecil ya saya ajarin sholat,ngaji, tapi saat remaja ini yo susah banget kalo disuruh sholat "(w2, ABD,22/10/2018)

"Ngajarin anak remaja sekarang untuk $k$ masjid itu gak gampang emang mnk, tapi saya kasih teladan saya ajak dan saya kasih reward awalnya, kalo sidah jadi kebiasaan ya alhamdulilah anak saya rajin sholat k masjid" (w2, SR,23/10/2018)

Saya tahu mbk, pendidikan agama itu emang penting buat anak-anak saya, tapi memang ngajarin anak jaman sekarang gak gampang, tapi saya dan bapaknya tetap sepakat anakanak harus diajarakan ibadah yang rajin,buat bekal mereka nanti juga, saya yakin kalo iman kita dan anak-anak kita kuat,mereka gak mudah terpengaruh buruk"(w2,AE,23/10/2018) 


\section{WACANA}

Hal tersebut senada dengan pendapat

Ada pepatah arab yang menjelaskan bagaimana penting peran ibu dalam pendidikan anaknya (Al Hisyamy. 1997), yang berbunyi:

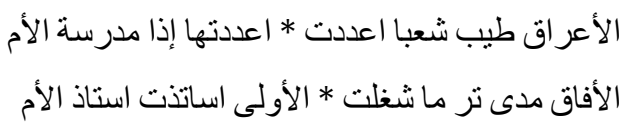

Artinya: Seorang ibu adalah madrasah apabila engkau mempersiapkannya, berarti engkau telah mempersiapkan suku bangsa dan generasi yang baik. Seorang ibu adalah guru pertama dan dari semua guru pertama yang pengaruhnya menyentuh jagad raya.

\section{SIMPULAN}

Hasil penelitian ini menunjukkan pentingnya optimalisasi peran orang tua dalam memahami remaja generasi milenial. Optimalisasi peran orang tua dikelompokkan dalam 4 kategori yaitu optimalisasi dalam peran pemenuhan kebutuhan ekonomi, fisik, psikologis, dan agama.

\section{DAFTAR PUSTAKA}

Ahmad Tafsir. 1992. Ilmu Pendidikan dalam Perspektif Islam. Bandung: Remaja Rosda Karya

Ali, M. \& Asrori, M. 2006. Psikologi Remaja, Perkembangan Peserta Didik Jakarta: Bumi Aksara.

Ayuningtyas, N., Y. 2011 "Maraknya Kriminalitas Di Kalangan Pelajar". Pendidikan Luar Sekolah Fakultas Ilmu Pendidikan. Yogyakarta: Universitas Negeri Yogyakarta.

Howe, N., \& Strauss, W. 2000. Millennials rising: The next great generation. New York: Vintage Books.

Kartini Kartono. 1995. Psikologi Anak: Psikologi Perkembangan. Bandung : CV Mandar Maju.

Monks, F.J. 2002 Psikologi Perkembangan: Pengantar Dalam Berbagai Bagiannya.Cet. 14.: Yogyakarta: Gajah Mada University Press

Muh. Ali Al Hisyamy. 1997. Jati Diri Wanita Muslimah, penerjemah: M. Abdul Ghoffar EM, Jakarta: Pustaka Al-Kaustar..

M. Ngalim Purwanto. 2007. Psikologi Pendidikan, Bandung: Remaja Rosdakarya. 
Roller, Margaret R., Lavrakas, Paul J.,2015 Applied Qualitative Research Design: A Total Quality Framework Approach, New York: The Guilford Press

Santrock, J.W. 2002. Life-Span Development: Perkembangan Masa Hidup (edisi kelima) (Penerj. Achmad Chusairi, Juda Damanik; Ed. Herman Sinaga, Yati Sumiharti). Jakarta: Erlangga.

Sarwono, S. 2011. Psikologi Remaja. Jakarta: PT. Raja Grafindo.

Syahminan Ziani dan Muhaimin Abdul Mujib. 1991. Belajar Sebagai Pengembangan Fitrah Manusia, Jakarta: Kalam Mulia

Taspcott, Don. 2008. Grown Up Digital: How the Net Generation is Changing Your World. McGraw-Hill.

Widyastuti, Rahmawati, Purnamaningrum. 2009. Kesehatan Reproduksi. Yogyakarta: Fitramaya

Wina Sanjaya. 2007. Strategi Pembelajaran Berorientasi Standar Proses Pendidikan, Jakarta: Kencana 